\title{
Geographical and temporal variation of regional development and innovation in Finland
}

\author{
TEEMU MAKKONEN AND TOMMI INKINEN
}

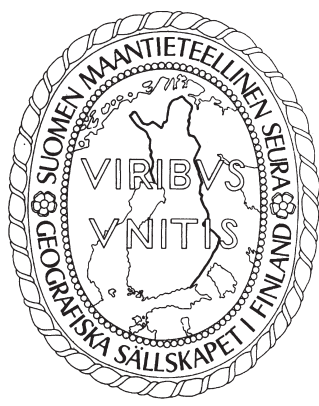

Makkonen, Teemu \& Tommi Inkinen (2015). Geographical and temporal variation of regional development and innovation in Finland. Fennia 193: 1, 134147. ISSN 1798-5617.

Variations in regional development are basically carried forward by technological development together with spatial concentrations of production and finance. The main argument behind this paper is that innovation and regional development variables have temporal variations in a spatial context. Analysis was conducted using principal component indices from the years 1995-2007 to provide a temporal trend perspective of the most successful locations in innovation activity and regional development. Availability of an extensive workforce, income and higher education have steadily been the most "distinct" variables corresponding to regional development in Finland, whereas innovation occupies a stable middling position among explanative variables. Regional development and innovation activity is still concentrated in the core urban regions, but this tendency has lost at least some of its importance.

Keywords: education, Finland, innovation, local administrative unit, principal component analysis, regional development

Teemu Makkonen, Department of Border Region Studies, University of Southern Denmark, Alsion 2, DK-6400 Sønderborg,Denmark.E-mail: teemu@sam.sdu.dk Tommi Inkinen, Department of Geosciences and Geography, University of Helsinki, P.O. Box 64, Fl-00014 Helsinki, Finland. E-mail: tommi.inkinen@helsinki.fi

\section{Introduction}

Regional innovation research has an extensive and rich history. As Copus et al. (2008) have argued, there are two lines of tradition for studying regional innovation activity in contemporary literature: region-focused and firm-focused. Thus, there is a dissonance in the literature on which factors (region-specific vs. firm-specific) are more significant in determining the total innovativeness of a region (Sternberg \& Arndt 2001). Following international trends (Shearmur 2011), Finnish innovation research has concentrated on firms (Ebersberger \& Lehtoranta 2005; Simonen \& McCann 2010). Still, arguably, the overall innovation performance is not dependent only on the innovation performance of firms, since regional knowledge resources, such as the existence of an educated workforce and a highly developed technology infrastructure, are crucial elements for regional innovation performance (Doloreux 2002; Fagerberg 2005).

What is agreed on in the most empirical research on innovation is that innovation has been assumed to be an important driver of economic development (e.g. van Oort 2002; Hasan \& Tucci 2010). This paper provides a regional case study analysis from Finland and attempts to explain temporal and geographical variations in regional development and innovation to assess these statements on the importance of innovation in regional development. The choice of case study location was motivated by Finland's measured success in international comparisons on innovation, education and other variables of regional development (e.g. Oinas 2005).

An extensive amount of work has already been conducted concerning regional development and innovation variables, but empirically they have 
been studied separately in Finland. Some scholars have addressed the issue of development and welfare (Siirilä et al. 2002; Lehtonen \& Tykkyläinen 2010), whereas others have concentrated their attention on research and development (R\&D) and innovations (Piekkola 2006; Valovirta et al. 2009). However, recent analysis by Makkonen (2011) shows the extent of interconnectedness between regional innovation variables and other regional variables of development and concludes that they are significantly correlated, but with a temporally limited dataset and without geographical considerations. This paper explores the geographical patterns of innovation and regional development in Finland by presenting the results of a multivariate analysis on the relationship between innovation activity and regional development in Finland. It also provides a temporal trend of the most successful locations in innovation activity and regional development. Additionally, since the strong Finnish geographical tradition on analysing regional development with multivariate methods seems to have almost faded away entirely, it is interesting to update the discussion on the factors contributing to regional development into a new millennium to see whether the composition of the explanative variables has changed to a significant degree (YliJokipii 2005).

The present work applies socio-demographic, economy-industry, and education and innovation variables, namely granted patents and R\&D activity in terms of expenditure, to assess regional development. In Finland, the innovation system is largely led by the national government. However, the innovation policy between regional and national arenas can be described as co-evolutionary (Sotarauta \& Kautonen 2007) and regional knowledge resources are dependent on regional socioeconomic variables. These location variables involve desirable housing options, social cohesion and sufficient economic activity. This leads us to the first research question:

(1) What are the most 'distinct' socio-economic variables jointly corresponding to regional development in Finland and how has the composition of these variables changed from 1995-2007?

The relationship between innovation and regional (economic) development has been described as bidirectional and accumulative (Gössling \& Rutten 2007; Makkonen \& Inkinen 2013). The level of development of a region affects the innovation output of that region, which in turn is transformed, directly or indirectly, to growth and further regional development. Therefore, the tendency to innovate and the ability to transform innovation into growth appear to concentrate geographically (Boschma \& Fornahl 2011). These notions create the foundation for the second research question:

(2) To what extend have regional development and innovation activities been concentrated on the core urban regions of Finland?

The paper shows that 1) innovation activities and socio-economic overall performance are not solely synonymous and that innovation activities have (only) a medium-level connection to other variables of regional development, 2) that workforce and higher education are nowadays the 'leading' variables for explaining regional development and 3) that where innovation is concerned traditional industrial regions in Finland have also been able to gain a position amongst the top regions.

\section{Regional development and innovation in earlier research}

\section{International and Finnish context}

International case studies and cross-country comparisons have suggested that there is a strong relationship between innovation activity and regional development. Social and economic conditions lead to different reactions to innovation and to development. Some regions exhibit stronger (innovation-prone) and some exhibit weaker (innovationaverse) than expected economic growth relative to their R\&D activity. Still, investments in economic and human resources, resulting in higher R\&D activities on the national and regional levels commonly pay off in economic terms, resulting in higher location-bound innovation production and growth (e.g. Rodríguez-Pose 1999; Agüeros et al. 2013). However, studies on European and US regions have shown that the developmental level of the region matters: investment and employment in R\&D activity require critical mass to gain positive marginal benefits (Varga 2000; Greunz 2005). Thus, innovation activity, as is regional development, is unevenly distributed across the global geographic landscape, between and within re- 
gions (Copus et. al. 2008). Moreover, innovation activities seem to cluster geographically (Florida 2002; Asheim \& Gertler 2005). All in all, the level and efficiency of innovation activity should be higher in the core urban regions than in more remote and peripheral regions (Fritsch 2004; Capello et al. 2012). Thus, as US studies have shown, although the core-periphery disadvantage may decrease, the peripheral and rural regions are still at a technological disadvantage where the geography of innovation is concerned (Ceh 2001; Monchuk \& Miranowski 2010). Indeed, both the results obtained with European firm-level data and the observations made with US data, have confirmed that innovation activities are geographically concentrated and their impacts highly localised Jaffe et al. 1993; Audretsch \& Feldman 1996; Sternberg \& Arndt 2001; Crescenzi \& Rodríguez-Pose 2013). In addition, regional concentration stimulates innovation, thus in general leaving the peripheral regions at a disadvantage on the levels of R\&D and innovation activity (Tödtling \& Trippl 2005).

The Finnish regional policy has traditionally been aimed at alleviating socio-economic differences between the most and the least developed regions through direct supportive funding, the relocation of national agencies and establishment of provincial universities (Tervo 2005; Jauhiainen 2008). Despite these efforts, marked regional variations in socio-economic development (or wellbeing) remain. Remote and rural municipalities, especially in northern and eastern Finland, still lag behind urban regions in southern and western Finland, when measured by unemployment or educational levels at least (Siirilä et al. 1990, 2002): in fact, Lehtonen and Tykkyläinen (2010) have demonstrated that, despite various policy measures, the self-reinforcing processes envisioned by classic cumulative causation theories (Myrdal 1969) still hold weight in Finnish regions and have resulted in a socio-economically polarized regional system. In other words, regional success has been concentrated in a small number of growth centres, of which the most evident example is the Helsinki capital region (Heikkilä 2003; Loikkanen \& Susiluoto 2012). On a national level migration and economic dynamics have caused polycentric concentration in other core urban regions, for example Oulu and Tampere (Antikainen \& Vartiainen 2005). Therefore, when considering Finland, the Helsinki capital region and other core urban regions have traditionally been in advantageous positions when compared with their peripheral coun- terparts. With specific reference to regional development and well-being, the evidence shows that the clustering of the population and economic activity has been centripetal (Mikkonen 2002; Siirilä et al. 2002; Lehtonen \& Tykkyläinen 2010).

In Finland the government-led innovation policy, which has been endorsed from the 1990s onwards, has been implemented through actions in line with the concept of national innovation systems together with regional cluster policies (Romanainen 2001; Miettinen 2002; Jauhiainen 2008). This has worked well, raising Finland up among the top-nations in country rankings of innovation (Oinas 2005). However, innovation activities are still mostly concentrated towards a few dominant core urban regions (Inkinen 2005).

\section{Measurement of regional development and innovation}

The term 'development' is in colloquial language associated with existing positive attributes resulting from progress. The main question, however, is which attributes are measured. Thus, the concept of development is largely a covenanted issue and requires agreement on what is measured (and to what extent) and how these measurements actually represent what is meant by development. Thus, the findings and propositions of earlier research are the foundations of the variable selection and index calculus. In our study, variable selection combines conceptual arguments with empirical observations; the variables appropriate for an applied theoretical framework provide higher validity and reliability (Isard et al. 1998). In choosing the variables, the criteria listed by the Advisory Board for Regional Development in Finland (Kehitysalueiden neuvottelukunta 1973), originally stated as 1) quantitative measurement, 2) instrumentality, 3) comprehensiveness, 4) significance, 5) disaggregability and 6) exclusiveness, were pursued. In addition, other studies of regional development in Finland (e.g. Siirilä et al. 1990, 2002; Rantala 2001; Mikkonen 2002; Lehtonen \& Tykkyläinen 2010, 2011) have been taken advantage of. For example, in these studies the economic success of regions was strongly associated with workforce properties. Therefore, our analysis includes variables on unemployment and the educational level and sectoral composition of the workforce. 
Moreover, variables commonly associated with regional economic development, i.e. variables on the income level and regional gross domestic product (GDP), where used to describe the efficiency and intensity of economic activity. The social structures of the regions were measured with data on migration and number of children and with variables related to social cohesion, namely dependency ratio and gender structure. The negative impacts of the concentration of population, where taken into account by using variables on housing conditions and the crime rate. To sum up, the variables chosen include various socio-economic variables, such as GDP, unemployment, sources of livelihood, and the percentage of the adult population with higher education (Table 1).

In the selection of study variables we also need to consider the temporal aspect of regional development, as what is 'agreed', in the literature, to constitute development changes over time (Pike et al. 2007). For example, the degrees of industrialization and services have been traditionally considered as the main indicators of development in individual locations (Dicken \& Lloyd
1991). However, since the 1990s innovationdriven developmental rhetoric has increased steadily (Jauhiainen 2008). Therefore, due to limitations in technology variables concerning regional development and growth, several other newly found concepts highlighting the importance of innovation have been used to describe this "techno-scientific" development (Nonaka \& Takeuchi 1995; Florida 2002; Webster 2002). However, there are problems in the measurement of innovation - defined in the traditional sense as the first introduction of an invention in the market (Sternberg 2009) - particularly in regional contexts, because the availability of coherent data from interregional sources is often limited. Therefore, R\&D and patent statistics were used here despite their limitation of being measures for technological product innovations (less suitable for measuring other types of innovation) and innovation inputs (rather than actual outputs), as they are among the most commonly used indicators of innovation, since they provide valuable information on the regional innovation activities and offer good regional data availability (Makkonen \& van der Have 2013).

Table 1. Chosen variables depicting regional development and innovation (in this study).

\section{Regional development}

\begin{tabular}{ll}
\hline Population change & Net population change \% (natural population change and migration) \\
Workforce & Percentage of population in workforce \\
Children & Percentage of children (under 15 years of age) \\
Dependency ratio & Amount of nonworking (unemployed, pensioners, children etc.) \\
Education & population compared with working population \\
Gender structure & Percentage of adult population with higher education \\
Unemployment & Number of women compared with 1000 men \\
Agriculture and forestry & Unemployment rate \% \\
Industry & Percentage of working population in agriculture and forestry sector \\
Service & Percentage of working population in industry sector \\
GDP & Percentage of working population in service sector \\
GDP change & Gross domestic product / inhabitant \\
GVA & Growth in gross domestic product \% \\
Income & Gross value added / inhabitant \\
Housing & Gross income / inhabitant \\
Crime & Percentage of small and/or inadequate housing \\
Patents granted & Crimes against human life and health compared with 1000 persons \\
R\&D spending & Patents granted / 1000 inhabitants \\
\hline
\end{tabular}




\section{Empirical material}

\section{Data considerations}

The analysed data was compiled and calculated from the official Statistics Finland's databases (AItika and StatFin). The calculations make the applied dataset unique; Statistics Finland, the provider of the original datasets, does not have these calculated data sources. The employment of Community Innovation Survey data was also considered. However, as a sample data of firms it poorly fits our purposes. The amounts of GDP and gross value added (GVA), as well as R\&D and patent data, were compiled from previous data from the older local administrative units (LAU-1) division. Consequently, a few smaller contemporary municipalities are misplaced in the LAU-1 division of 2010 used in this study. The missing data on certain LAU-1s from individual years were estimated as the moving averages of contiguous years. The percentage of missing data points in the original dataset is $1.7 \%$. In addition, the classification of higher education in the Finnish official statistics changed in 1998 so the data from 1995-1997 is based on an earlier educational division. The data were gathered from the years 1995-2007.

In spatial terms, the data covers all (68) of the LAU-1s in mainland Finland and Åland as a whole due to missing data on the LAU-1 level in Åland (Fig. 1). The unit of observation issues was considered according to Glaeser (2000), who discussed the problems of analysis with spatial units. The use of LAU-1 classification was decided because it has considerably more units than the old nomenclature of territorial units for statistics (NUTS) classification, regional scale used for example in Regional Innovation Scoreboard of the European Union (Hollanders et al. 2009), enabling the use of statistical methods with available innovation data. The smaller LAU-2 units still suffer from a too large extent of missing data.

There are also some limitations to LAU- 1 categories, because in a respect they present "a medium" option. The selection is however grounded because the regional concept of LAU-1 is a more coherent regional entity that would better entail the idea of "functional area" in regional analyses rather than LAU-2 which involves more detailed information on a legislative municipal level. The $\mathrm{LAU}-1$ units are thus a good compromise in terms of 'local' and 'regional', because in Finland they

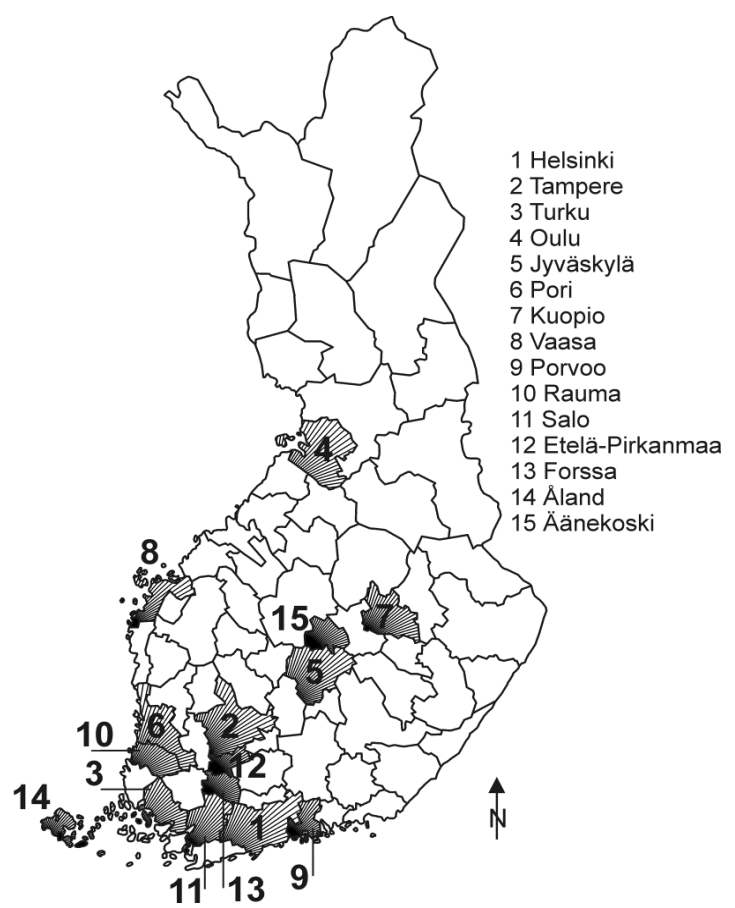

Fig. 1. Finnish LAU-1 division in 2010 (regions mentioned in the text are highlighted).

are more robust concerning functional areas of daily commuting. Finally, the innovation policy is strongly influenced by the national level (Sotarauta \& Kautonen 2007). Moreover, LAU-1 level regions do not have a direct role in local innovation systems but they always include the smaller regional units of cities and municipalities that may organize their own respective development functions.

\section{Remarks on principal component analysis (PCA)}

Finland has a long history of geographical studies on regional development with multivariate methods (Yli-Jokipii 2005). Here, also, regional development was measured with a combination of variables describing regional development and innovation activity for which multivariate analysis provided the best analytical toolkit. PCA was used for several reasons. First, it is robust enough to withstand limitations in missing values, considering the overall size of the data $(\mathrm{N}=69)$ that 
can be considered as average in regional studies. The missing case treatment used in this study also provided a decent alternative for conducting PCA without risking the reliability or validity of the study. Second, PCA is a good tool for identifying patterns and highlighting similarities and differences within the data. In a regional context, this is particularly beneficial. Notwithstanding, and even though there is ample empirical support to underline the importance of endogenous socioeconomic factors for local economy and innovation processes (e.g. Crescenzi et al. 2007), the limitation of the "spatial objects PCA" approach applied here is that it does not take into account the possible impacts of spatial autocorrelation (Demšar et al. 2013).

PCA compresses the information contained by several variables into a small number of principal components (dimensions), which ensures that as little of the original information as possible is lost. At the same time, the impacts of different variables on regional development are weighted. Here, also, lies the value added of PCA. Recently, studies on regional development in Finland (e.g. Siirilä et al. 2002; Makkonen 2011) have taken the variables employed as granted without testing the importance and the composition of these variables against regional development as a whole. PCA in turn offers a means of exploring the interconnectedness and the weight of different variables of regional development, which allows us to investigate which variables, in fact, are 'important' for regional development. Analysis also indicates the underlying dimensions that unify the groups of variable loadings on each principal component. The methodological considerations and applications of PCA can be found in Jolliffe (2002) and Tabachnick and Fidell (2007). The most common tests (the Bartlett test of sphericity

Table 2. Key figures of PCA for "regional development".

\begin{tabular}{lccccc} 
& 1995 & 1998 & 2001 & 2004 & 2007 \\
\hline KMO & 0.686 & 0.719 & 0.733 & 0.717 & 0.705 \\
Bartlett's & $<0.001$ & $<0.001$ & $<0.001$ & $<0.001$ & $<0.001$ \\
Eigenvalues & 8.563 & 8.905 & 8.626 & 8.520 & 8.034 \\
\% of variance & 47.57 & 49.47 & 47.93 & 47.34 & 44.63 \\
\hline
\end{tabular}

and the Kaiser-Meyer-Olkin (KMO) measure of sampling adequacy) and measures (communalities, loadings and eigenvalues) of PCA suitability were used in this study.

PCA always requires meaningful interpretations for the principal components produced. Otherwise, another method should be used. The designation of the principal component reflects the interpretation, because it requires consideration of what types of variables are loaded on the principal component. Therefore, it is important that the name given to the principal component describes the aggregate that it represents. Additionally, the research design of this study asks how regions are situated in relation to the principal component scores (PCS). Calculation of the PCS is carried out in a similar fashion to that of the regression model by weighting the variables with coefficients produced by PCA. The advantage of this approach lies in the way that changes in PCS will reflect both the importance (loadings) of the various indicators included in the analysis over time and shifts in regions' positions relative to each other (Fagerberg et al. 2007). However, at the same time this renders the statistical comparison of PCS between different years less feasible. Thus, the decision to concentrate on the regions' standings based on the PCS was made, i.e. the relative differences between the regions are not shown in our results.

\section{Key results of principal component analysis}

The preconditions for successful PCA were fulfilled in the data concerning variables used to assess regional development for every year (Table 2). A large number of variables showed significant loadings concerning the first principal component (Table 3). The first principal components can thus be interpreted as "regional development". This paper will now focus further on the interpretation of these first principal components.

As Table 3 suggests, a significant workforce and higher education are the "leading and distinct" variables of regional development (in terms of covariation of the explanatory variables) giving an answer to the first explicit research question. This means that an educated workforce correlates highly with other indicators depicting regional development and can be described as an important re- 
Table 3. Loadings of the principal component "regional development" for the years 1995, 1998, 2001, 2004 and 2007 (arrows represent the subsequent shifts in the order of the variables according to their values of principal component loadings; loadings under the value of 0.3 are excluded).

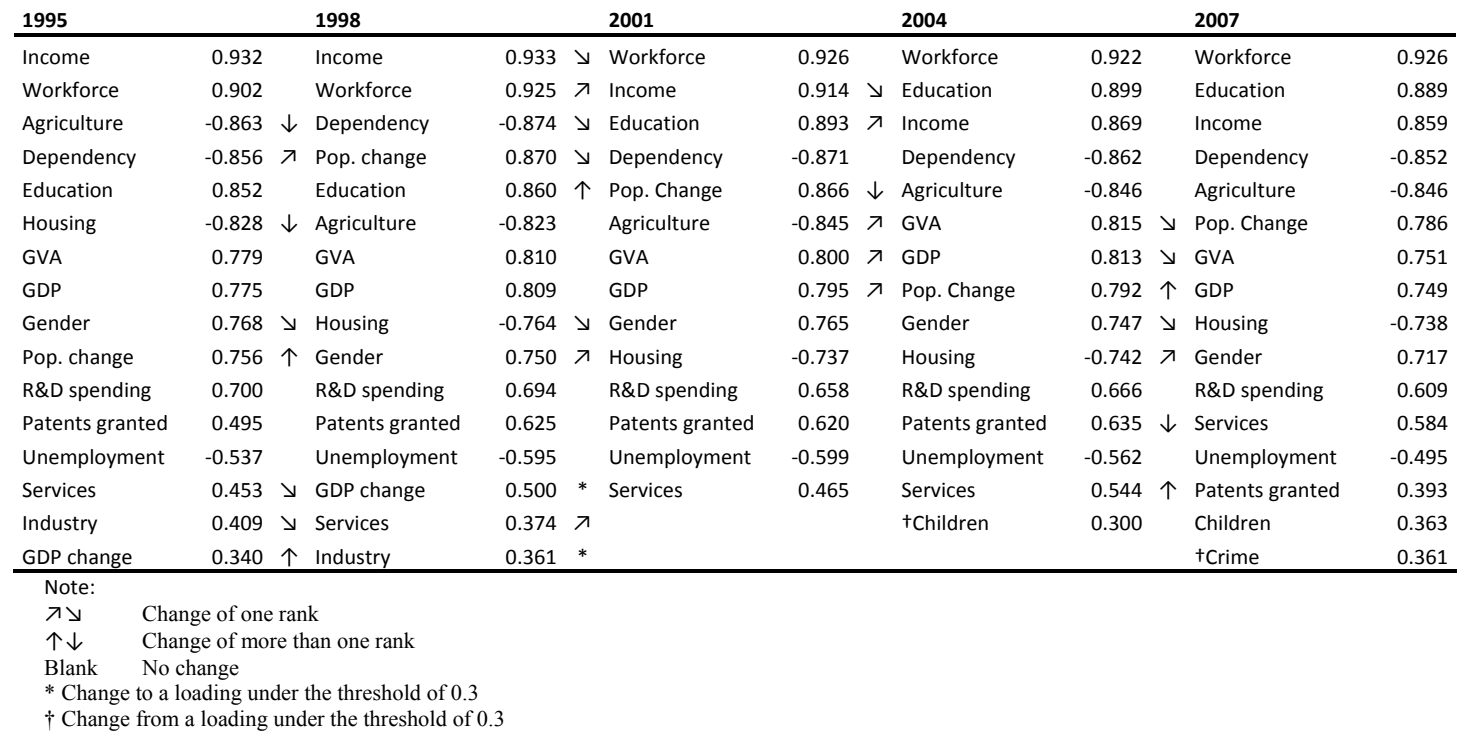

source for regional development. The changes in the composition of the leading variables have been subtle. Table 3 shows, however, that workforce and higher education have preceded income level in terms of loadings, which in the 1990s was still the single most 'distinct' variable corresponding to regional development. The changes in the order of the other variables are more sporadic when all the years (1995-2007) are considered, although the dependency ratio and agriculture and forestry are now established as the fourth and fifth most 'distinct' variables of regional development. Population change is also positively associated with regional development. In addition, GVA, income, and GDP are high in more developed regions. Since agriculture and forestry are negatively associated with other variables depicting regional development, it can be stated that predominantly rural regions are not at the peak of development and it appears that more developed regions are in fact service-oriented (services are positively associated with other variables depicting regional development). Accordingly, unemployment, limited and low housing conditions and a high depend- ency ratio are negatively, whereas a nonbiased gender structure is positively, associated with other variables depicting regional development.

The variables chosen here to depict innovation, namely R\&D spending and patents, have gained a stable middling position (in terms of covariation of the explanatory variables) among the other variables of regional development. The recent decrease in the loadings of patents is evident from the total number of patents in Finland (Fig. 2), which have declined drastically since 2005. In contrast, the amount spent in R\&D in Finland has increased steadily and the loadings of R\&D have not undergone such distinct changes than patents. Also, the time lag for the economic realization of patents is longer (Makkonen 2011). However, it has to be noted that R\&D activities and patents reflect only a part of the total innovation inputs and outputs. Thus, the total innovative efforts in a region are not represented through these two variables. Furthermore, outsourcing and dispersal of firm's innovation activities to outside its home-region can lead to an underestimation of the real innovativeness of some regions and overestimation of others. 


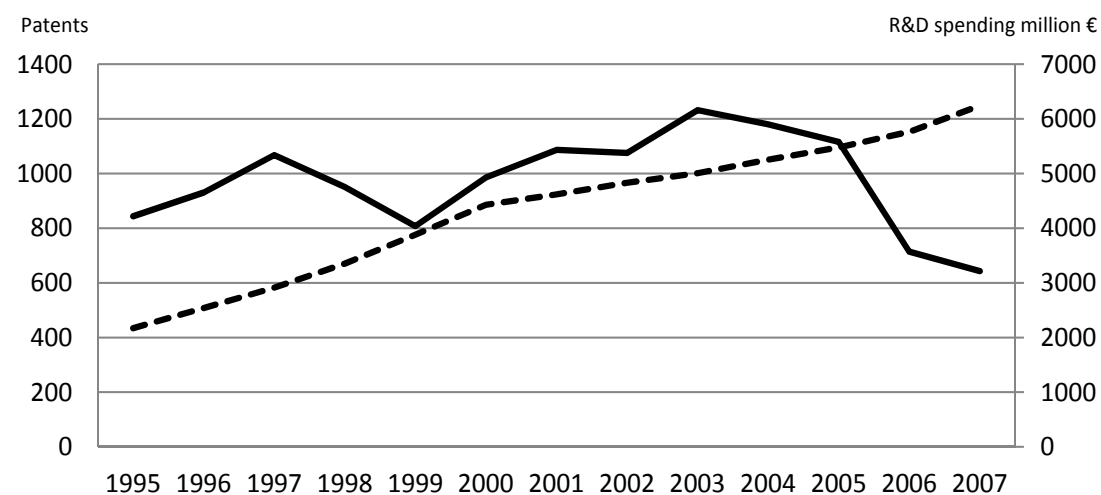

1995199619971998199920002001200220032004200520062007

Patents _- - R\&D spending

Loadings

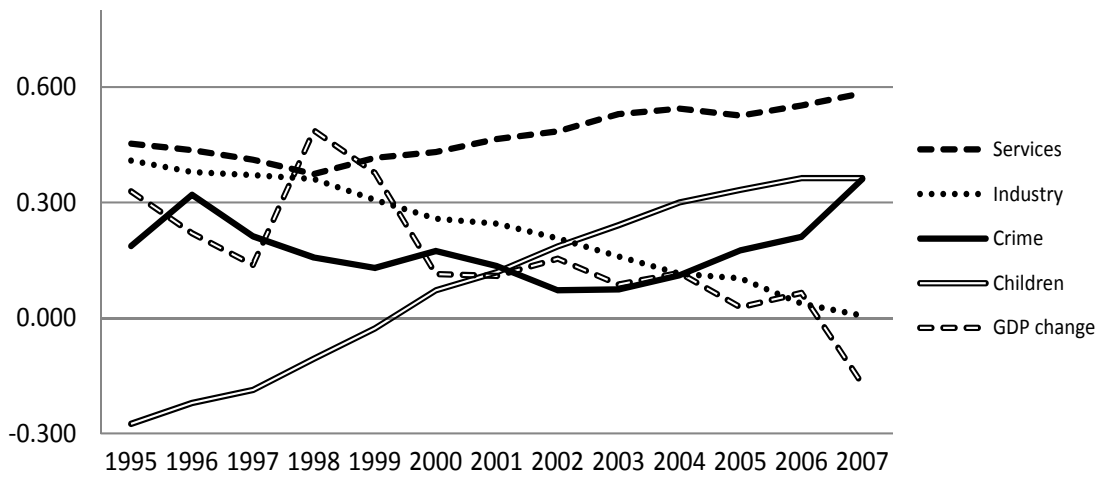

Fig. 2. The total number of patents and combined R\&D spending in Finnish LAU-1s.
Fig. 3. Selected extracts of the loadings of different variables to "regional development".
Some minor changes that are not evident from the Table 3 are highlighted in Figure 3 which suggests that industry is no more a 'distinct' feature of regional development. An opposite path to industry can be seen in the importance of services. In the mid-1990s services and industry had almost equal loadings, but after 1998 these two variables have taken quite different directions: the loadings of services have increased steadily whereas the loadings of industry have fallen to negligible. Industry was at one time almost a synonym for development, but it has been replaced by other more sophisticated "techno-scientific factors". Since the loadings of the principal component are low, the percentage of children and levels of crime are not associated with regional development to a noticeable degree. However, it is inter- esting that the loadings of the percentage of children to the regional development have increased from a negative effect to a modest positive association. This means that the positive connections between the number of children and the other variables of regional development are likely to strengthen in the future. On the contrary GDP change, which had a modest association with regional development in the 1990s, has now fallen under a loading of 0.3 , which means that nowadays it does not have a notable connection to other variables depicting regional development. This is an interesting side note, which is hard to explain as it would seem plausible that GDP growth should be interlinked with regional development. One reason is the use of LAU-1s as the units of observation. In LAU-1s, there are tremen- 
dous fluctuations in the growth percentage of GDP between individual years.

According to previous literature, innovation variables are associated with the variables of regional development. In line, the results presented here are somewhat encouraging: in Finland innovation was positively associated with regional development. However, innovation is not among the predominant variables (in terms of covariation of explanatory variables) of regional development. In fact there are several other variables with higher loadings to regional development than innovation. Thus, innovation variables, R\&D spending and granted patents are interlinked with the other variables depicting regional development, but they are not among the "leading and distinct" variables of regional development.

\section{Innovation and principal component scores for regional development}

The following comparisons are based on variations between a sum ranking of patents and R\&D spending (the standings of the regions in both patent and R\&D rankings were summed up: low scores indicate good performance) and the PCS ranking of "regional development" (where 0 indicates the average and positive value above average performance). As seen from the PCS rankings, the most developed regions in Finland are the core urban regions (Fig. 4 and Table 4). In contrast the rural and peripheral parts of eastern and northern Finland are less developed. Regional clustering is clearly visible: provincial centres have higher data scores than surrounding regions.

The PCS rankings show that statistically the most developed regions are also the most innovative (Fig. 4 and Table 4). Their counterparts are the rural and peripheral regions, which also have the lowest R\&D inputs and patenting intensity. To single out one region, Åland, is a clear exception to this positive correlation rule, because it has high developmental scores but low scores for innovation variables. The autonomous Åland differs considerably from the regions of continental Finland in terms of economic activity. For example, leisure travel is a high income source in Aland and one factor explaining this anomaly. The most innova-

Table 4. The most innovative, in the sum ranking of R\&D spending and granted patents, regions in Finland and the standings in the principal component score ranking of "regional development" for the years 1995, 2001 and 2007.

\begin{tabular}{|c|c|c|c|c|c|c|c|}
\hline \multicolumn{4}{|c|}{ Innovation } & \multicolumn{4}{|c|}{ Regional development } \\
\hline & 1995 & 2001 & 2007 & & 1995 & 2001 & 2007 \\
\hline 1 & Oulu & Oulu $\downarrow$ & Tampere & 1 & Helsinki & Helsinki & Helsinki \\
\hline 2 & Salo & Salo $\downarrow$ & Vaasa & 2 & Turku $\downarrow$ & Tampere & Tampere \\
\hline 3 & Jyväskylä $\downarrow$ & Helsinki & Helsinki & 3 & Oulu & Oulu & Oulu \\
\hline 4 & Helsinki & Tampere $\uparrow$ & Oulu & 4 & Åland & Åland & Åland \\
\hline 5 & Tampere $\lambda$ & Jyväskylä & Jyväskylä & 5 & Tampere $\uparrow$ & Turku \ & Vaasa \\
\hline 6 & Porvoo & Porvoo* & Salo & 6 & Salo $\downarrow$ & Porvooy & Turku \\
\hline 7 & Etelä-Pirkanmaa & Etelä-Pirkanmaa* & †Forssa & 7 & Porvoo & Jyväskylä $\downarrow$ & Porvoo \\
\hline 8 & Vaasa & Vaasa $\uparrow$ & Äänekoski & 8 & Vaasa & Vaasa $\uparrow$ & Salo \\
\hline 9 & Turku & Turku* & tRauma & 9 & Jyväskylä & Salo $\nearrow$ & Jyväskylä \\
\hline 10 & Forssa* & †Äänekoski个 & tPori & 10 & Kuopio & Kuopio & Kuopio \\
\hline
\end{tabular}

\begin{tabular}{ll}
\hline Note: & \\
$\nearrow \searrow$ & Change of one rank \\
$\uparrow \downarrow$ & Change of more than one rank \\
Blank & No change \\
$*$ & Has fallen outside the top ten \\
$\dagger$ & New in top ten
\end{tabular}


A
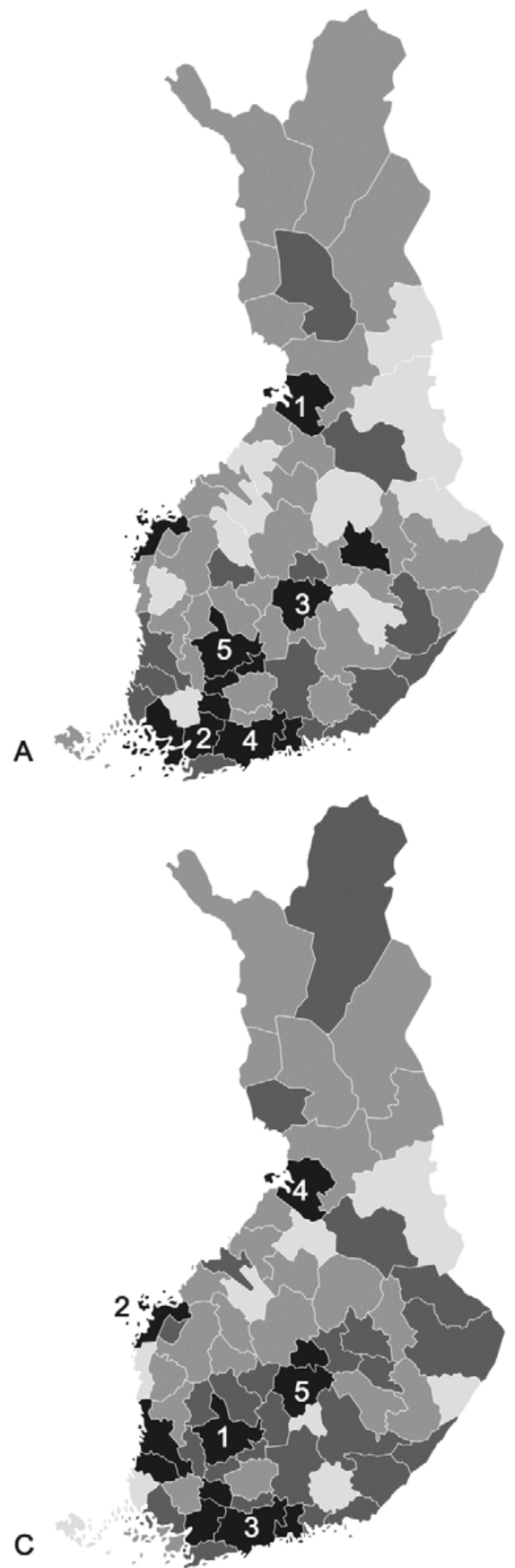

Highest

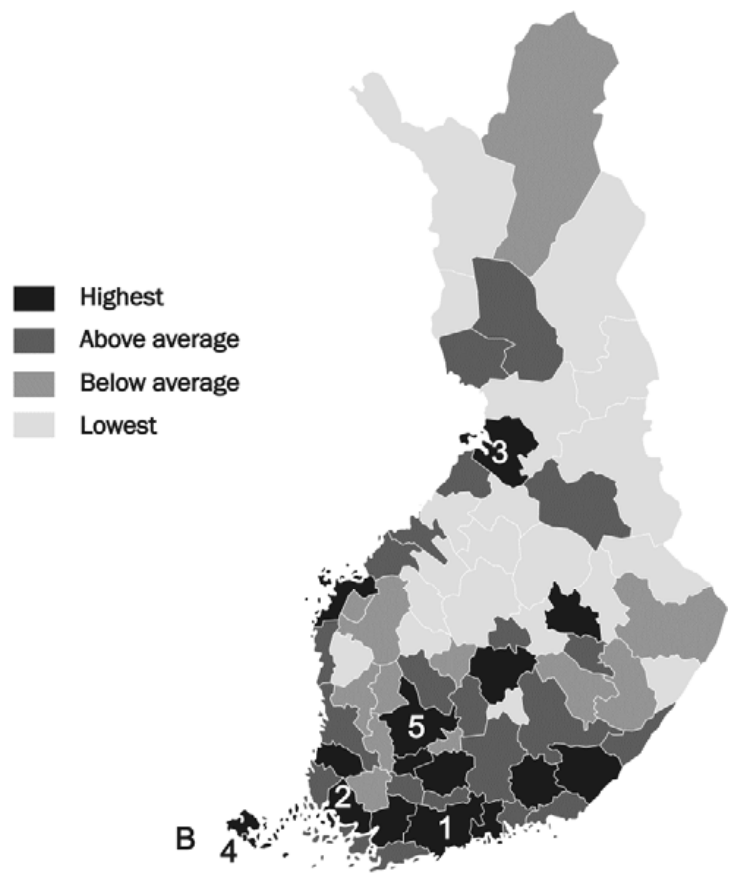

Above average

Below average

Lowest

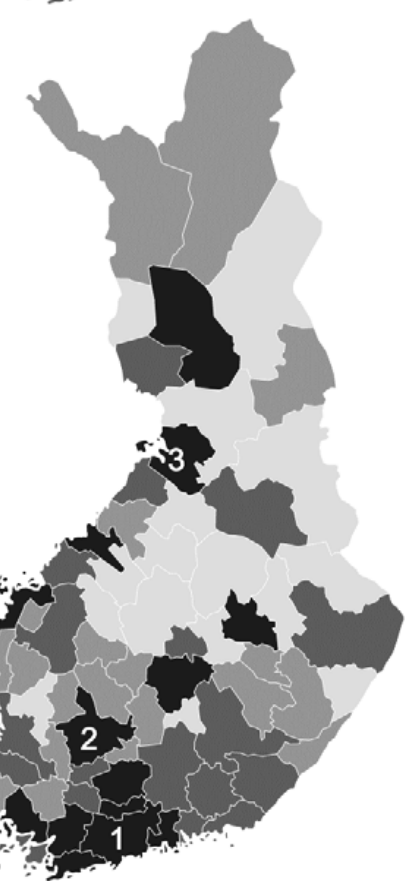

Fig. 4. Sum ranking scores of R\&D spending and granted patents in A) 1995 and C) 2007 (highest $\leq 35$; above average $=36-75$; below average $=76-105$; lowest $>105$ ) and principal component score rankings for LAU-1 "regional development" in B) 1995 and D) 2007 (highest > 0.75; above average $=0.00-0.75$; below average $=$ $-0.75-0.00$; lowest $<-0.75$ ). For explanation of the numbers, see Table 4. 
Table 5. Size classes of Finnish regions (average population 1995-2007).

\begin{tabular}{|c|}
\hline Over 200000 inhabitants $(n=3)$, including: \\
\hline Helsinki; Tampere; Turku \\
\hline 100000 - 200000 inhabitants $(n=7)$, including: \\
\hline Oulu; Jyväskylä; Pori; Kuopio \\
\hline 50000 - 99500 inhabitants $(n=14)$, including: \\
\hline Vaasa; Porvoo; Rauma; Salo \\
\hline 25000 - 49500 inhabitants $(n=23)$, including: \\
\hline Etelä-Pirkanmaa; Forssa; Åland \\
\hline Below 25000 inhabitants $(n=22)$, including: \\
\hline Äänekoski \\
\hline
\end{tabular}

tive, in terms of patents and R\&D spending, (and developed) regions are consistently university regions (one visible exception is the region of Salo). The relatively high position of the Salo region in the R\&D and patents ranking was due to Nokia's strong influence in the region: Nokia's R\&D conducted in Finland still accounted for almost half of the total business sector R\&D in Finland ten-tofive years ago (Ali-Yrkkö \& Hermans 2004).

As for the changes in time it can be said that the extremes in innovative regions have narrowed between the years 1995-2007: the explicit dualism between the urban and peripheral regions has decreased (Fig. 4 and Table 4). Still, Oulu, Jyväskylä, Tampere, Helsinki, and Vaasa are and have been the most innovative region, in terms of $R \& D$ spending, and among the top regions measured in patents, in Finland during the time period analysed. However, there are also highly innovative regions that have developed themselves with the significant branches of traditional forest and marine industry. These regions include Äänekoski (a strong forest industry region), Rauma and Pori (both important marine industry regions). They are now among the most innovative regions in Finland, whereas at the beginning of the observation period the most innovative regions were more predominantly core urban regions (cf. Table $5)$. The changes in the order of the most developed regions have been subtler and there have been shifts back and forth, but Helsinki maintained its position as the most developed region between the years 1995-2007.

In sum, the core urban regions are still the drivers of the national economy. Interestingly, the regions in Figure 4 and Table 4 are rather dispersed throughout Finland. Thus, multi-centrality is also visible and provincial centres tend to have high innovation capacities. However, the northern and eastern parts are still underrepresented in terms of regional development and innovation. The comparisons show that, innovation and regional development are positively associated. This was evident from the results of the PCA, which show that the innovation variables were loaded on the first principal component depicting regional development.

\section{Discussion and implications}

The case study location, Finland, has been considered as one of the countries that have been the most successful at creating and promoting innovation through a national innovation system together with regional cluster policies. Finnish regional policy has a long tradition of balancing goals in regional development. In theory, all municipalities should provide the same conditions for the quality of life throughout the country. However, in geographical terms, the results show that the developmental level in Finland follows a north-south trend, with the exception of provincial centres, following the existence of the main explanative variables: the southern parts are the most developed, but provincial centres in other parts of Finland also emerge as developed locations. Moreover, some traditional industry regions have gained a position among the most innovative regions in Finland. As stated, the most developed regions in Finland are also among the most innovative regions. Although other significant socioeconomic variables have to be taken into account, one can see a two-way implication: innovations boost regional development and developed regions are more prone to innovation. Thus, steps to promote innovation can also be seen as steps to improve the developmental stage of a region.

The broader implications derived from the results have interesting insights for other countries, besides Finland, to follow regionally inclusive growth paths. First, the heavy investments on education in Finland appear to have paid off in (regional) economic terms. Second, indicatively the success of a variety of regions in terms of regional development and innovation points towards a conclusion that the Finnish way of implementing cluster based regional development and innovation policies seems to have worked relatively well as pointed out by Valovirta et al. (2009). However, 
third, relying solely on techno-scientific inputs (R\&D) in regional development does not guarantee economic growth. Fourth, the development policies aimed at alleviating the differences between the most and the least developed regions in Finland (Jauhiainen 2008) seem to have, in their part, secured a multi-centred landscape of economic activities. Thus, in short, these successful Finnish examples offer guiding lines to other countries aiming at implementing regionally-balanced development policies.

\section{Conclusions and remarks for future research}

This paper explained the temporal variations of regional development in the light of innovation production. The variables used are interrelated and jointly contribute to regional development, but the analysis illustrates that workforce and higher education has replaced income levels as the "leading and distinct" variables of regional development, even though temporal changes may be considered modest. Thus, to answer the first research question, workforce and higher education are the 'leading' variables for explaining regional development, whereas innovation activity is only of mediocre importance in explaining regional development and economic success. This is partly to do with the time lag between innovation variables and their economic realization, but it also shows that, even though innovative activity might be important for regional development, other actions including the support of education and attracting a (skilled) workforce should not be ignored vis-à-vis regional development policies.

To answer the second research question, the empirical results show that the levels of regional development and innovative activity are higher in the core urban regions than in the periphery, i.e. innovation and regional development appear to cluster geographically. Statistics support the statements that peripheral regions are at a disadvantage on the levels of $R \& D$ and innovation production. However, this tendency of clustering of innovative activities towards the core urban regions has levelled off to some extent.

In conclusion the data were collected in Finland and thus the results are pertained to the situation in Finland. In other countries the contexts are different and the implemented policies and public sector functions concerning regional development may also vary. However, the results provide a coherent comparative starting point, at least for other countries with similar GDP and R\&D levels. Furthermore, the LAU-1 classification is an official statistical unit currently used in the European context. LAU-1 classification provided a more robust way to understand regional variations compared to NUTS-3 classification that we consider too broad and general for innovation analysis. Accordingly, applying innovation output data as in Makkonen and van der Have (2013) as well as other (less common) indicators of regional development might raise interesting further insights into the relationship between innovation and regional development. Finally, more qualitative and quantitative approaches are needed in order to assess the impacts of innovation activities and policies in the regional level. An extensive amount of work has already been conducted separately, but the triangulation of quantitative variables to ad hoc qualitative data as well as applying PCA with spatial autocorrelation (see Demšar et al. 2013) requires further efforts.

\section{ACKNOWLEDGEMENTS}

This work is a part of the project 127213 funded by the Academy of Finland. We thank Mr. Arttu Paarlahti, Dr. Gareth Rice and the anonymous reviewers for their help in improving the paper.

\section{REFERENCES}

Agüeros $M$, Casares-Hontañón $P$, Coto-Millán $P$, De Castro P \& Pesquera M 2013. A new approach to innovation and its application to the countries of the European Union. Quaestiones Geographicae 32: 2, 5-14. http://dx.doi.org/10.2478/quageo-2013-0009.

Ali-Yrkkö J \& Hermans R 2004. Nokia: A giant in the Finnish innovation system. In Schienstock G (ed). Embracing the knowledge economy: The dynamic transformation of the Finnish innovation system, 106-127. Edward Elgar, Cheltenham.

Antikainen J \& Vartiainen P 2005. Polycentricity in Finland: From structure to strategy. Built Environment 31: 2, 143-152.

http://dx.doi.org/10.2148/benv.31.2.143.66257.

Asheim B \& Gertler M 2005. The geography of innovation: Regional innovation systems. In Fagerberg J, Mowery D \& Nelson R (eds). The Oxford handbook of innovation, 291-317. Oxford University Press, Oxford. 
Audretsch D \& Feldman M 1996. R\&D spillovers and the geography of innovation and production. American Economic Review 86: 3, 630-640.

Boschma R \& Fornahl D 2011. Cluster evolution and a roadmap for future studies. Regional Studies 45: 10, 1295-1298. http://dx.doi.org/10.1080/00343404.2011.633253. Capello R, Caragliu A \& Lenzi C 2012. Is innovation in cities a matter of knowledge-intensive services: An empirical investigation. Innovation - European Journal of Social Science Research 25: 2, 151-174. http://dx.doi.org/10.1080/13511610.2012.660326.

Ceh B 2001. Regional innovation potential in the United States: Evidence of spatial transformation. Papers in Regional Science 80: 3, 297-316. http://dx.doi.org/10.1007/PL00013634.

Copus A, Skuras D \& Tsegenidi K 2008. Innovation and peripherality: An empirical comparative study of SMEs in six European Union member countries. Economic Geography 84: 1, 51-82.

http://dx.doi.org/10.1111/j.1944-8287.2008.tb00391.x.

Crescenzi R \& Rodríguez-Pose A 2013. R\&D, socioeconomic conditions, and regional innovation in the U.S. Growth and Change 44: 2, 287-320. http://dx.doi.org/10.1111/grow.12011.

Crescenzi R, Rodríguez-Pose A \& Storper M 2007. The territorial dynamics of innovation: A Europe-United States comparative analysis. Journal of Economic Geography 7: 6, 673-709. http://dx.doi.org/10.1093/jeg/lbm030.

Demšar U, Harris P, Brunsdon C, Fotheringham AS \& McLoone S 2013. Principal component analysis on spatial data: An overview. Annals of the Association of American Geographers 103: 1, 106-128.

http://dx.doi.org/10.1080/00045608.2012.689236.

Dicken P \& Lloyd P 1991. Location in space: Theoretical perspectives in economic geography. Longman, London.

Doloreux D 2002. What we should know about regional systems of innovation. Technology in Society 24: 3, 243-263.

http://dx.doi.org/10.1016/S0160-791X(02)00007-6.

Ebersberger B \& Lehtoranta O 2005. Patterns of innovative activities among Finnish firms. VTT, Espoo.

Fagerberg J 2005. Innovation: A guide to the literature. In Fagerberg J, Mowery D \& Nelson R (eds). The Oxford handbook of innovation, 1-26. Oxford University Press, Oxford.

Fagerberg J, Srholec M \& Knell M 2007. The competitiveness of nations: Why some countries prosper while others fall behind? World Development 35: 10, 1595-1620. http://dx.doi.org/10.1016/j.worlddev.2007.01.004.

Florida R 2002. The rise of the creative class. Basic Books, New York.

Fritsch M 2004. Cooperation and the efficiency of regional R\&D activities. Cambridge Journal of ECOnomics 28: 6, 829-846.

http://dx.doi.org/10.1093/cje/beh039.

Glaeser E 2000. The new economics of urban and regional growth. In Clark G, Feldman M \& Gertler M (eds). The Oxford handbook of economic geography, 83-98. Oxford University Press, Oxford.
Gössling T \& Rutten R 2007. Innovation in regions. European Planning Studies 15: 2, 253-270. http://dx.doi.org/10.1080/09654310601078788.

Greunz L 2005. Intra- and inter-regional knowledge spillovers: Evidence from European regions. European Planning Studies 13: 3, 449-473.

http://dx.doi.org/10.1080/09654310500089746.

Hasan I \& Tucci C 2010. The innovation-economic growth nexus: Global evidence. Research Policy 39: 10, 1264-1276.

http://dx.doi.org/10.1016/j.respol.2010.07.005.

Heikkilä E 2003. Differential urbanisation in Finland. Tijdschrift voor Economische en Sociale Geografie 94: 1, 49-63.

http://dx.doi.org/10.1111/1467-9663.00236.

Hollanders H, Tarantola S \& Loschky A 2009. Regional innovation scoreboard 2009. European Commission, Brussels.

Inkinen T 2005. European coherence and regional policy: A Finnish perspective on the observed and reported territorial impacts of EU research and development policies. European Planning Studies 13: 7, 1113-1121.

http://dx.doi.org/10.1080/09654310500242139.

Isard W, Azis I, Drennan M, Miller R, Saltzman S \& Thorbecke E 1998. Methods of interregional and regional analysis. Ashgate, Aldershot.

Jaffe A, Trajtenberg M \& Henderson R 1993. Geographic localization of knowledge spillovers as evidenced by patent citations. Quarterly Journal of Economics 108: 3, 577-598.

http://dx.doi.org/10.2307/2118401.

Jauhiainen J 2008. Regional and innovation policies in Finland: Towards convergence and/or mismatch? Regional Studies 42: 7, 1031-1045. http://dx.doi.org/10.1080/00343400701543140.

Jolliffe I 2002. Principal component analysis. Springer, New York.

Kehitysalueiden neuvottelukunta 1973. Vyöhykejaon tutkimusryhmän raportti: Selvitys kehittyneisyyden alueellisista eroista ja aluejakovaihtoehdoista aluepolitiikassa. Valtioneuvoston Kanslian Julkaisuja 1973: 2.

Lehtonen O \& Tykkyläinen M 2010. Self-reinforcing spatial clusters of migration and socio-economic conditions in Finland 1998-2006. Journal of Rural Studies 26: 4, 361-373.

http://dx.doi.org/10.1016/j.jrurstud.2010.02.003.

Lehtonen O \& Tykkyläinen M 2011. Spatial divergence in living standards during an economic growth phase in the periphery: A case study of North Karelia. Fennia - International Journal of Geography 189: 2, 47-62.

Loikkanen H \& Susiluoto I 2012. Suurimpien seutukuntien kokonaistaloudellinen kehitys 19752008. Helsingin Kaupungin Tietokeskus, Helsinki.

Makkonen T 2011. Innovation and socio-economic development: evidence from the Finnish local administrative units. Bulletin of Geography - Socioeconomic Series 15: 1, 27-42.

http://dx.doi.org/10.2478/v10089-011-0002-0. 
Makkonen T \& Inkinen T 2013. Innovative capacity, educational attainment and economic development in the European Union: Causal relations and geographical variations. European Planning Studies 21: 12, 1958-1976. http://dx.doi.org/10.1080/09654313.2012.722968.

Makkonen T \& van der Have RP 2013. Benchmarking regional innovation performance: Composite measures and direct innovation counts. Scientometrics 94: 1, 247-262. http://dx.doi.org/10.1007/s11192-012-0753-2.

Miettinen R 2002. National innovation system: Scientific concept or political rhetoric? Edita, Helsinki.

Mikkonen K 2002. The competitive advantage of regions and small economic areas: The case of Finland. Fennia - International Journal of Geography 180: 2, 191-198.

Myrdal G 1969. Ekonomisk teori och underutvecklade regioner. Tidens Förlag, Stockholm.

Monchuk D \& Miranowski J 2010. The impact of local innovation and innovative spillovers on employment and population growth in the U.S. Midwest. Journal of Regional Analysis and Policy 40: 1, 61-70.

Nonaka I \& Takeuchi H 1995. The knowledge-creating company. Oxford University Press, Oxford.

Oinas P 2005. Finland: A success story? European Planning Studies 13: 8, 1227-1244. http://dx.doi.org/10.1080/09654310500336618.

Piekkola H 2006. Knowledge and innovation subsidies as engines of growth: The competitiveness of Finnish regions. ETLA, Helsinki.

Pike A, Rodríguez-Pose A \& Tomaney J 2007. What kind of local and regional development and for whom? Regional Studies 41: 9, 1253-1269. http://dx.doi.org/10.1080/00343400701543355.

Rantala O 2001. Regional economic development in Finland in the 1990s and the outlook to 2005. Finnish Economy and Society 2, 64-70.

Rodríguez-Pose A 1999. Innovation prone and innovation averse societies: Economic performance in Europe. Growth and Change 30: 1, 75-105. http://dx.doi.org/10.1111/0017-4815.00105.

Romanainen J 2001. The cluster approach in Finnish technology policy. In den Hertog P, Remoe S, Bergman E \& Charles D (eds). Innovative clusters: Drivers of national innovation systems, 377-388. OECD, Paris.

Shearmur R 2011. Innovation, regions and proximity: From neo-regionalism to spatial analysis. Regional Studies 45: 9, 1225-1243.

http://dx.doi.org/10.1080/00343404.2010.484416.
Siirilä S, Hautamäki L, Kuittinen J \& Keski-Petäjä T 1990. Regional well-being variations in Finland. Fennia - International Journal of Geography 168: 2, 179-200.

Siirilä S, Vaattovaara M \& Viljanen V 2002. Well-being in Finland: A comparison of municipalities and residential differentiation in two cities. Fennia - International Journal of Geography 180: 2, 141-149.

Simonen J \& McCann P 2010. Knowledge transfer and innovations: The role of the labour markets $R \& D$ co-operation between agents and institutions. Papers in Regional Science 89: 2, 295-309. http://dx.doi.org/10.1111/j.1435-5957.2010.00299.x.

Sotarauta M \& Kautonen M 2007. Co-evolution of the Finnish national and local innovation policy approach. Regional Studies 41: 8, 1085-1098. http://dx.doi.org/10.1080/00343400701292284.

Sternberg R 2009. Innovation. In Kitchin R \& Thrift N (eds). International encyclopedia of human geography, 481-490. Elsevier, Amsterdam.

Sternberg R \& Arndt O 2001. The firm or region: What determines the innovation behaviour of European firms? Economic Geography 77: 4, 364-382. http://dx.doi.org/10.1111/j.1944-8287.2001.tb00170.x.

Tabachnick B \& Fidell L 2007. Using multivariate statistics. Pearson Education, Boston.

Tervo H 2005. Regional policy lessons from Finland. In Felsenstein D \& Portnov B (eds). Regional disparities in small countries, 267-282. Springer-Verlag, Berlin.

Tödtling F \& Trippl M 2005. One size fits all: Towards a differentiated regional innovation policy approach. Research Policy 34: 8, 1203-1219. http://dx.doi.org/10.1016/j.respol.2005.01.018.

Valovirta V, Pesonen P, Halonen M, van der Have RP \& Ahlqvist T 2009. Suomalaisten innovaatioiden maantiede. Työ- ja elinkeinoministeriö, Helsinki.

van Oort F 2002. Innovation and agglomeration economies in the Netherlands. Tijdschrift voor Economische en Sociale Geografie 93: 3, 344360. http://dx.doi.org/10.1111/1467-9663.00207.

Varga A 2000. Local academic knowledge transfers and the concentration of economic activity. Journal of Regional Science 40: 2, 289-309. http://dx.doi.org/10.1111/0022-4146.00175.

Webster F 2002. Theories of information society. Routledge, London.

Yli-Jokipii P 2005. Suomen alueellinen kehittyneisyys ja aluepolitiikka maantieteen tutkimuskohteena. In Moisio S (ed). Maantiede mun silmäni avaa, maapalloa katselemaan, 9-21. Turun yliopisto, Turku. 